$\diamond \diamond ミ ニ レ ヒ ゙ ュ ー \diamond \diamond$

\title{
トランスポーターを介した薬物動態制御
}

\section{Membrane Transporters as Determinant of Drug Absorption and Disposition}

\author{
玉井 郁巳 \\ 金沢大学薬学部
}

\begin{abstract}
Summary: Although passive diffusion, which depends on the lipid solubility, is a fundamental mechanism for the membrane transport of many of compounds, water-soluble compounds also cross cell membranes by the specialized carrier-mediated transport mechanisms. We have demonstrated that several drugs are transported by the tissue-specific transporters in intestinal and renal epithelial cells, hepatocytes and brain capillary endothelial cells which form the blood-brain barrier. They include oligopeptide transporter, monocarboxylic acid transporter, anion antiporter, organic anion transporter, and P-glycoprotein. Most of them functions for the uptakes of drugs into the cells leading to the increased permeability, others exclude drugs out of cells, thereby decreasing apparent permeability into cells. It was also found that a certain drug which crosses by the certain transporter in the intestinal membranes is sometimes recognized by the other transporter, or not recognized by transporters in other tissues. This finding demonstrates that it would be possible to expect tissue specific delivery of drugs by utilizing transporters which have different characteristics among tissues. Such a difference in permeability among tissues would be difficult to expect when the membrane transport is carried out by passive diffusion. There are more evidences for carrier-mediated transport of many drugs in various tissues other than mentioned in the present study. Further mechanistic clarification and quantitative analysis of pharmacokinetic importance of such transporters will help the development of effective strategies for the site specific drug delivery.
\end{abstract}

\section{1 はじめに}

薬物の生体膜透過は基本的には各薬物の分子サイズ, 脂溶性, 水素結合能などの物理化学的特性に依存する単 純拡散に従い, 特にイオン性薬物の場合には非解離形分 子の及が膜透過する $\mathrm{pH}$-分配仮説により説明される.

しかし, 細胞内外の効率的な物質交換活性が必要な小 腸, 腎尿細管, 胎盤, 脳脈絡叢の上皮細胞や肝実質細 胞, 血液脳関門などでは, 多くの薬物は単純拡散以外の 特異的機構により細胞膜を透過する．をた，脂溶性の高 い脂肪酸のような物質も細胞内移行に膜タンパク質の関 与があり 11 , 単純拡散と思われていた生体膜輸送にも卜 ランスポーターが介在している可能性がある.

臨床的には薬物動態に標的部位選択性が望まれるが,
単純拡散による膜透過では選択性を期待するのは困難で ある。一方, トランスポーターは各臟器が持つ生理的役 割に応じて備わっており, 分布や機能に臓器特異性が期 待される.すなわち, 薬物動態に蔵器選択性をもたらす 手法の一つとしてトランスポーターの有用性が期待でき る. 我々らはトランスポーターの薬物動態影響因子とし ての重要性と, その薬物デリバリーへの応用のための基 礎的情報を得ることを目的とし, 種々臓器における薬物 輸送研究を行ってきた．本ミニレビューではその成果の 一部を述べる.

\section{2 消化管吸収過程}

小腸上皮細胞には多くのトランスポーターが存在し， 薬物吸収あるいは分泌に働いている2).

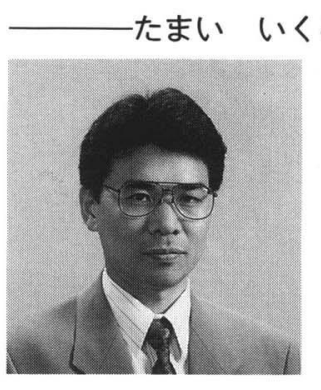

玉井郁巳 : 1959年岐阜生屯れ.1982年金沢大学薬学部卒業後, 辻 彰教授のもとで一貫し てトランスポーターを介した薬物の膜輸送研究を行っており，1996年助教授. 現在に至る. 1989年から留学し P-糖蛋白質研究の指導を受けた米国シカゴ大学 Safa 博士, 消化管吸収研 究の指導を受けたミシガン大学 Amidon 教授, さらに現在東北大学の寺崎哲也教授からの刺 激も受け, 小腸, 肝蔵, 腎臓, 血液脳関門, 腫瘍細胞など様々な臓器におおる薬物輸送に興味 を持っている. 薬物動態研究に少しでも貢献できるよう今後もトランスポーター研究を進めた い. 
$\beta$-ラクタム抗生物質は臨床上繁用される安全性の高 い抗菌薬であり，ペプチド系化合物として分類される. 本抗生物質は水溶性であるためその誘導体の多くは経口 吸収されないが，側鎖 $\alpha$ 位にアミノ基を有する両性イ オン型誘導体（アミノ- $\beta$-ラクタム抗生物質）は経口吸 収性が良好である.アミノー $\beta$-ラクタム抗生物質はアミ ノ末端を有するため他の吸収性に劣る誘導体に比べ天然 のペプチドと構造上の類似性が高く，上皮細胞膜透過に ペプチド輸送系の関与が1975年 Addison 等により示唆 されだ).ペプチド輸送系はジあるいはトリペプチドを 認識するが，テトラペプチド以上は輸送できずペプチド サイズについてはきわめて厳格であるが，ペプチドが非 天然のアミノ酸から構成されたものであれ受け入れる幅 広い基質認識性を持つ。したがって, 経ロ $\beta$-ラクタム 抗生物質の消化管吸収にも本輸送系の関与が考えられる に至った. 1975年以後, 我々を含む複数の研究グルー プによりペプチド輸送系を介するアミノー $\beta$-ラクタム抗 生物質の吸収が報告された5)。一方，アミノ基を欠いた アニオン型 $\beta$-ラクタム抗生物質の中にも吸収性に優れ た誘導体が開発された. Fig. 1 に示すセフィキシム， セフチブテン, FK089 が該当する. いずれもジカルボ ン酸構造を有しており, 吸収上皮細胞膜表面酸性 $\mathrm{pH}$ に おいても油/水分配係数はきわめて小さく，それらの良 好な吸収性は単純拡散では説明できなかった。

我々は, セフィキシム, FK089 の小腸上皮細胞膜透 過機構についてラット小腸刷子縁膜小胞，および反転腸 管を用いた解析を行った ${ }^{6-9)}$. 両化合物とも，プロトン 勾配を駆動力とする担体介在輸送が示された. なた，セ フィキシムの刷子縁膜小胞への取り込みはアミノ酸や有 機アニオン性化合物の影響を受けないが，ジ・トリペプ
チドにより特異的に阻害され，ペプチド輸送系を介する 吸収機構が示された. さらに，アミノー $\beta$-ラクタム抗生 物質に加えペプチド輸送系に認識されないと考えられて いたアニオン型 $\beta$-ラクタム抗生物質によっても阻害さ れた. 以上の結果は, 小腸ペプチド輸送系が $\beta$-ラクタ 厶抗生物質を認識する際に側鎖 $\alpha$ 位アミノ基が必須で はないことを示し，本輸送系を介した薬物吸収を考える うえで新たな情報となった。

一方， $\beta$-ラクタム抗生物質の吸収におけるトランス ポーターの関与について否定的な考え方もあった． それ は，合成脂質膜リポソームにおけるイオン性化合物の輸 送に競合阻害やpH依存性が観測されること，吸収に動 物種差が認められること, さらに $\beta$-ラクタム抗生物質 誘導体間でトランスポーターが必ずしも共通とはいえな いことなどであった ${ }^{2)}$.このような点を解明するために はそれまでの薬物輸送の膜生理学的研究のみからでは困 難であり，輸送タンパク質の存在，および再構築系によ る機能の実証が必要である. 我々は一つの方法として, 外来性遺伝子発現系であるアフリカツメガエル卵母細胞 を用い，小腸上皮細胞 mRNA 中における $\beta$-ラクタム抗 生物質輸送タンパク質遺伝子の有無を調べた ${ }^{10,11)}$ 。 その 結果, mRNA 注入卵母細胞では, ジカルボン酸型誘導 体セフチブテン，拉よびアミノー $\beta$-ラクタム抗生物質セ ファドロキシルに新たに $\mathrm{pH}$ 依存的な輸送活性が現れ， 飽和性やジ・トリペプチドによる特異的阻害効果など, 刷子縁膜小胞実験系などとまったく同じ特性が観測され た.さらに，ヒトおよびウサギ小腸由来 mRNA も同じ く輸送活性を呈した。以上の外来性遺伝子発現系を用い た輸送活性の再構築は, $\beta$-ラクタム抗生物質が動物種 を問わずトランスポーターを介して吸収されることを実

\section{アミノー $\beta$-ラクタム抗生物質}
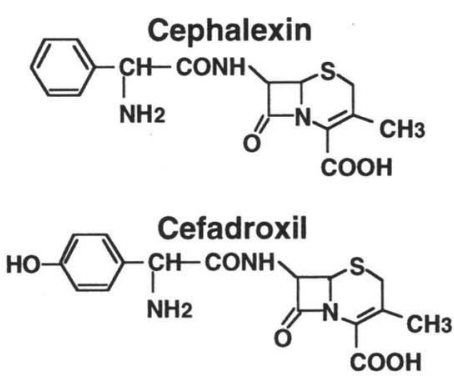

Cephradine

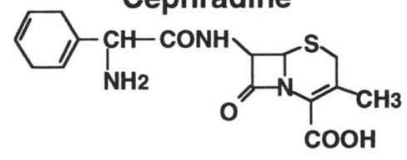

モノカルボン酸型 ß-ラクタム抗生物質

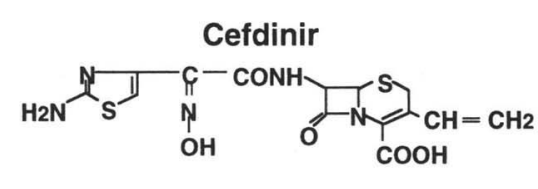

\section{Cefazolin}

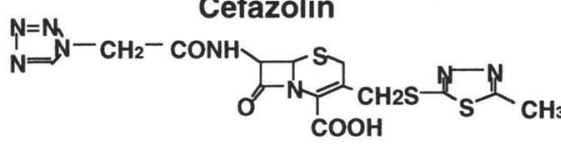

$\mathrm{COOH}$
ジカルボン酸型 ß-ラクタム抗生物質
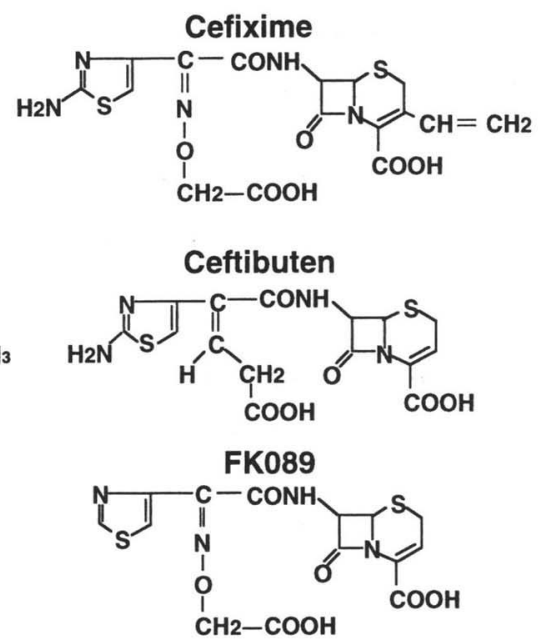

Fig. $1 \beta$-ラクタム抗生物質の構造式と分類 


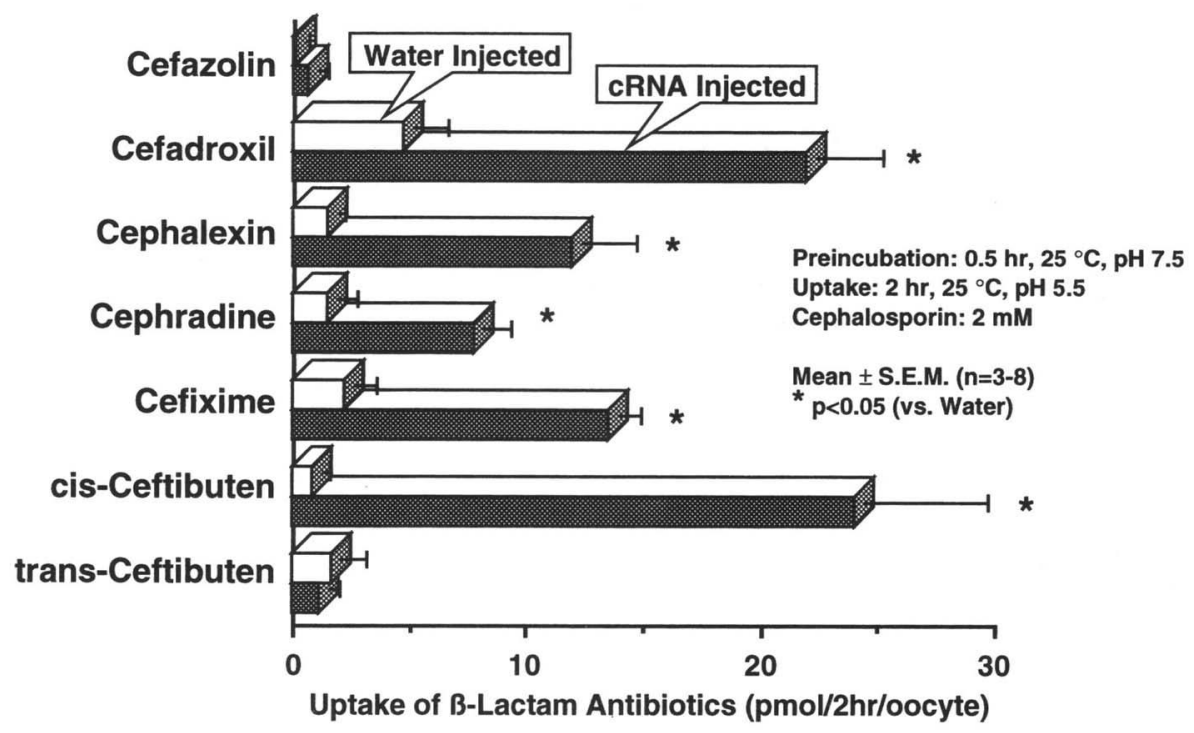

Fig. 2 ラットPepT1-cRNA を注入したアフリカッメガエル卵母細胞への種々 $\beta$-ラクタム抗生物質の取り込み

証するものであった。しかし，小腸由来全 mRNA を用 いた本実験結果からのみではトランスポーターの同定に は至らず, 輸送系の多様性についても明らかにできなか った：はからずも1994年, Fei らはウサギ小腸オリゴぺ プチドトランスポーターPepT1 のクローニングに初め て成功した ${ }^{12)}$. 我々および Saito らは, ウサギ PepT1 を元にラット小腸から $77 \%$ の相同性を持つラット PepT1 を得た ${ }^{13,14)}$.ラットPepT1 は710個のアミノ酸 から成り, 分子量 $79 \mathrm{kDa}$ で12力所の膜貫通部位を持つ と推測される典型的な膜輸送タンパク構造を有してい た. 本遺伝子の機能をPepT1 cRNA を発現させた卵母 細胞を用いて検討した。 ジペプチド $\left[{ }^{14} \mathrm{C}\right] \mathrm{Gly}-\mathrm{Sar}$ と， 我々の目的とする $\beta$-ラクタム抗生物質の卵母細胞への 取り込みはいずれも cRNA 注入により顕著に增加し, その活性は膜生理学的解析によって得られた輸送特性と 一致した。しかも, 経口吸収性の良好な誘導体はいずれ も有意な輸送活性を示したが，非経口的に用いられるセ ファゾリンの活性は現れず (Fig. 2), $\beta$-ラクタム抗生 物質の吸収はペプチド輸送系を介することが実証され た.

さらに明確にする必要があるのは輸送系の多様性の問 題であった。我々はアンチセンス DNA を用いたhybrid depletion 法を用い，ラットおよびウサギ小腸全 mRNA に含まれる PepT1 遺伝子の発現を抑制させ た ${ }^{15)}$. その結果, セフチブテンの輸送活性は, アンチ センス DNA 存在下で対照である水注入々同程度まで減 少した。この結果は, $\beta$-ラクタム抗生物質の担体輸送 がほぽPepT1によって賄われていることを示す。ただ し，アンチセンス DNA 合成部分と相同性の高い遺伝子 配列を有する他のトランスポーターの関与は否定できな い.すでに我々らは, 経口投与されるモノカルボン酸型
誘導体セフジニルはペプチド以外にモノカルボン酸とし ても認識される可能性を示した ${ }^{16)}$ したたかって，これ までに研究対象となった $\beta$-ラクタム抗生物質の吸収は PepT1 でほぼ説明できるが，一部の誘導体には PepT1 以外の輸送系の関与を否定できない.

ペプチド輸送系はその機能から小腸上皮細胞刷子縁膜 に存在するものと推定されていた，しかし，その実証は ないため, 我々らはPepT1に対する抗ぺプチド抗体を 作製し小腸組織内分布を調べた．その結果，刷子縁膜側 にのみ本抗体による明確な反応が観測され，本トランス ポーターの刷子緑膜における存在が初めて明らかにされ た15).

我々は，その後クローニングされたヒトPepT1 を米 国ジョージア医科大学 Leibach 教授から譲り受け, 同 じく卵母細胞により輸送特性を調べたが，ヒトPepT1 は基質認識性などについてラットやウサギPepT1 とま ったく同じ輸送特性を持つことが確認された. 以上述べ た著者の属する研究室における消化管吸収に関する 20 年におよぶ研究成果の積み重ねにより, 動物種を問わず, $\beta$-ラクタム抗生物質の消化管吸収におけるペプチド輸 送系の重要性が実証されるに至った.

従来より単純拡散と思われていた吸収にトランスポー ターの関与を示した例としてモノカルボン酸系化合物が ある.モノカルボン酸系化合物に代表される弱酸性化合 物の膜透過は酸性 $\mathrm{pH}$ で増大するが，この現象は従来よ り $\mathrm{pH}$-分配仮説に従う単純拡散によって説明されてい る.しかし，実測される消化管吸収- $\mathrm{pH}$ プロファイル は必ずしも本仮説に従わないため, 非摚找水層や酸性微 小 $\mathrm{pH}$ 環境の存在など単純拡散機構による吸収に基づい た修正理論が適用されてきた。これに対して我々は $\mathrm{pH}$ 依存的トランスポーターの重要性を提唱した ${ }^{2,17)}$ 。二コ 


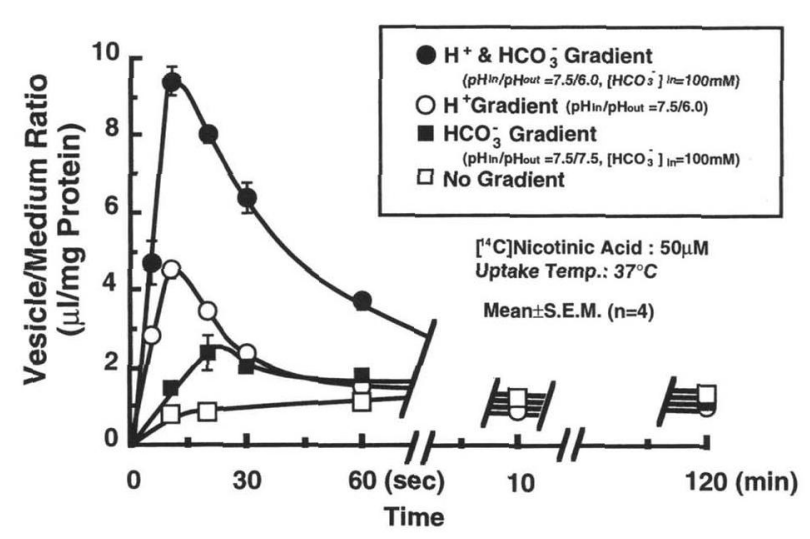

Fig. 3 二コチン酸のウサギ小腸刷子縁膜小胞への取り込みに おけるプロトンおよび重炭酸イオン効果

チン酸, 乳酸, 安息香酸, 高脂血漿治療薬プラバスタチ ンなどについて刷子縁膜小胞や Caco-2 細胞を用いた解 析を行ったが, 1 例としてニコチン酸の膜小胞への取り 込及実験結果を Fig. 3 に示す．明らかにプロトン共輸 送系とアニオン逆輸送系の関与を示す特徵がみられ

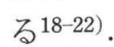

プロトン共輸送体の一つとして，1994年に CHO 細胞 よりクローニングされたモノカルボン酸トランスポータ 一 MCT1 の関与を考えている. 我々は CHO-MCT1 と 相同性の高いラットMCT1 小腸から得た ${ }^{23,24)}$ 、本遺 伝子産物の輸送機能を卵母細胞を用いて解析した結果,

乳酸, ピルビン酸, 酶酸などの短鎖脂肪酸, ニコチン酸 などの輸送活性が増大し, MCT1 がプロトン共輸送の 一端を担うことが示唆された. ラットMCT1は多くの 組織に分布し，特に心臓に多量に発現する ${ }^{24)}$. MCT1 が各組織で，取り込久あるいは排出いずれの向に働い ているかは明かではないが, 各臓器においてモノカルボ ン酸系化合物の動態に影響を及ぼしているものと思われ る.

モノカルボン酸のアニオン逆輸送に働くトランスポー ターとしては, Band3に代表されるアニオン逆輸送 (AE) ファミリーが一部関与すると考えている. 赤血 球には従来より乳酸などのモノカルボン酸系化合物に対 してプロトン共輸送系の寄与が知られている.さらに必 ずしも明確ではないが，一部 Band3 を介したホスホエ ノールピルビン酸など有機酸輸送の示唆もある.我々は AE2 が小腸上皮細胞の刷子縁膜に存在すること, モノ カルボン酸系化合物が重炭酸イオンと逆輸送されるこ

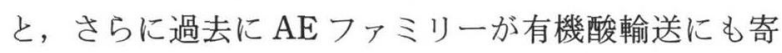
与している示唆があることから, 小腸上皮刷子縁膜に存 在する AE2 がモノカルボン酸系化合物の輸送にも働く と考えた. 米国スタンフォード大学 Kopito 教授より譲 り受けたAE2 遺伝子25)を発現させた HEK293 での輸 送活性を測定した ${ }^{26)}$. $\left.{ }^{14} \mathrm{C}\right]$ 安息香酸の取り込みを Fig.

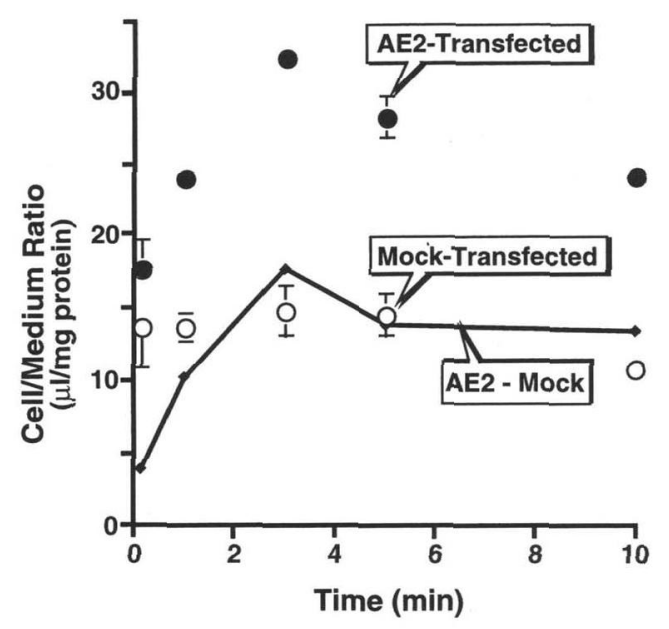

Fig. 4 AE2 を発現させた HEK293 細胞への安息香酸の取り 込みの時間推移

4 に示すが, AE2 導入により顕著な取り込み増大が観 測された。 さらに, DIDS や塩素イオンによる阻害もみ られ，モノカルボン酸系化合物に働くアニオン逆輸送系 の一つとしてAE2 の寄与が示された.

しかし，ここで述べたプロトン共輸送系 MCT1 とア ニオン逆輸送系 AE2 のみで全てのモノカルボン酸系化 合物の吸収が説明されるわけではなく，多様な輸送系の 関与があるものと考えている。

Fig. 5 は脂溶性一小腸吸収速度の関係を示す27). 多 くの化合物について実線のように脂溶性とともに吸収性 が増大し, やがて非擋挥水層透過律速と思われる頭打ち 現象がみられるが，一方で著しく低い吸収性を示す化合 物群がある. 我々はその吸収性の低い原因として消化管 腔内分泌機構の関与を考えている. 著者は, 1980年代 終わりに当時癌細胞の多剂耐性化の主因として注目され ていた P-糖蛋白質の正常組織における機能に関心を抱 き, 留学先の米国シカゴ大学にて Safa 博士とともに免 疫抑制剤シクロスポリンが基質結合部位を競合すること により，P-糖蛋白質機能を阻害することを明らかにし た ${ }^{28)}$. P-糖蛋白質は癌細胞外へと抗がん風を能動的に 汲み出すトランスポーターとして機能し, 抗がん剂の細 胞内蓄積量を減少させるため耐性化を引き起こす， P糖蛋白質は消化管を含め多くの正常組織に存在する29) が, 正常細胞においても同様に機能すれば薬物の組織移 行性低下につながることは容易に考えられた．Fig. 5 に はシクロスポリン存在下で測定した吸収性を合わせて示 す. 程度の差はあるが吸収性は矢印で示されるように一 様に増大した．この結果は, $\mathrm{P}$-糖蛋白質による管腔内 分泌がこれら薬物の低吸収性の原因であることを示唆す るものである. しかし, 実線で示された值が脂溶性のみ で説明できる吸収速度とすれば, P-糖蛋白質以外の吸 收性低下因子が考えられ，この点については現在明確な 


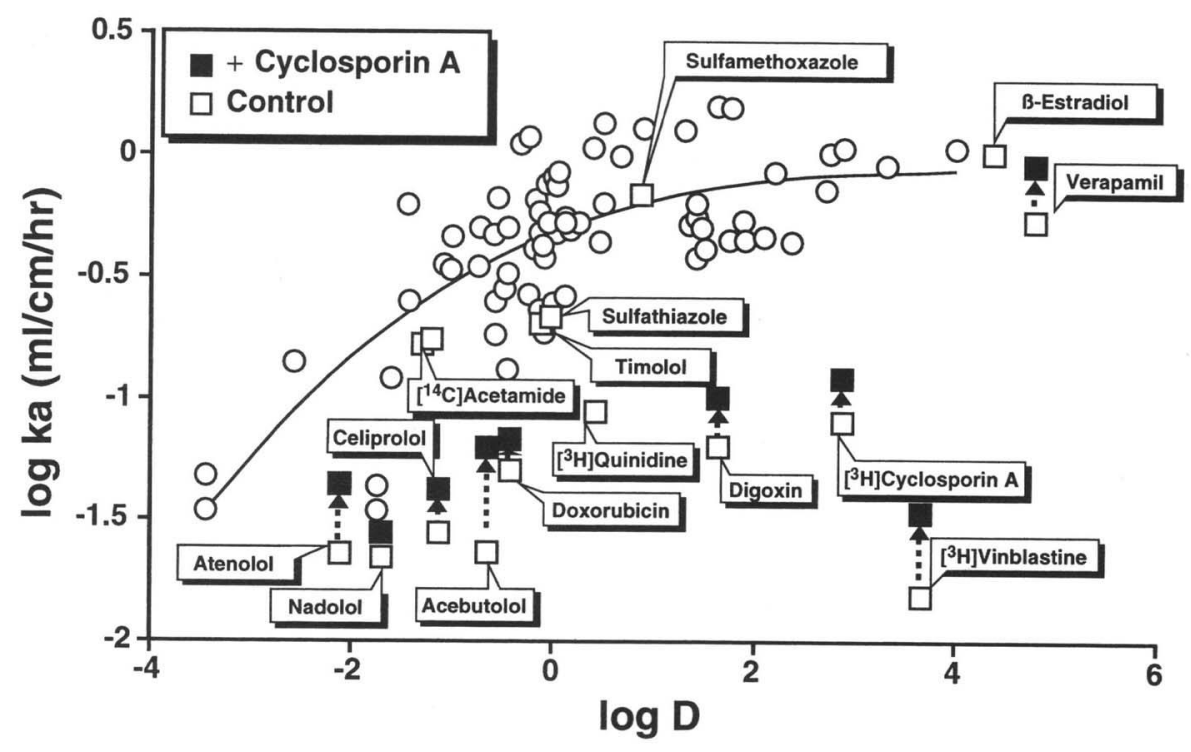

Fig. 5 化合物の脂溶性と消化管吸収性の相関

答えはない，後述するように $\mathrm{P}-$ 糖蛋白質は種々臓器で 移行障壁として働き, また他の細胞外への汲久出しに働 くトランスポーターも存在すると考えられる. 吸収方向 のみならず管腔内分泌（細胞外排出）についても今後検 討を深める必要がある。

\section{3 組織分布過程一血液脳関門透過一}

血液一脳細胞間液空間の物質交換は血液脳関門を形成 する脳毛細血管内皮細胞を隔てて行わ机る.この内皮細 胞は密着結合しているため物質移動は経細胞的であり, 一般的には脂溶性により透過性が決まる。しかし, 実際 には脳内移行・脳外排出ともに様々なトランスポーター が作用し, 脂溶性とは無関係に活発な物質輸送が行われ ている30)。血液脳関門トランスポーター研究は, 手法 上の困難さのために他の組織ほど明快な結論が得られて いない. 我々は脳毛細血管内皮細胞初代培養系を導入 乙, 脳灌流法や脳微小透析法などのin vivo 実験手法と 合わせて血液脳関門研究を行った.

古くより血液脳関門には乳酸などを輸送するモノカル ボン酸トランスポーターの存在の示唆があるが，その実 体として我々は, 前述した MCT1 の関与を考えている. ラット脳毛細血管内皮細胞より得た mRNA を用いた検 討から, 小腸と同一の MCT1 遺伝子の存在が示され た24).さらに, 初代培養内皮細胞を用いた検討により 血管側・脳側両細胞膜で MCT1 様輸送特性が検出され, 取り达み・排出両方向に MCT1 が働いていることが示 された ${ }^{31)}$. HMG-CoA 還元酵素阻害薬プラバスタチン は前述したように小腸からはプロトン共輸送により吸収 され22), また標的臟器の肝へもアニオン輸送系を介し て効率よく移行する ${ }^{32}$. しかし血液脳関門のモノカル
ボン酸トランスポーターに対する親和性は低く，また水 溶性のため脳内移行性は低くなり，その結果，中枢性副 作用も低いと考えられる33). 一方，プラバスタチンの 脂溶性構造類似体のシンバスタチンなどは単純拡散によ る吸収と藏器分布が生じ, また中枢性副作用もプラバス タチンより強い。これは, 水溶性 HMG $\mathrm{CoA}$ 還元酵素 阻害薬の場合はトランスポーターを利用するために小腸 吸収および標的臓器とする肝移行性が良好であるが，他 の組織でのトランスポーターには低親和性であるため臓 器移行性に選択性が賦与されたものと推測される。一 方, 脂溶性誘導体は単純拡散により非特異的に臓器移行 するため選択性が期待できず，トランスポーターの利用 が臓器選択的薬効発現に有効であることを示す一例と思 われる17)。その他にも我々は血液脳関門能動輸送系々 して $\mathrm{Na}^{+}, \mathrm{Cl}^{-}$依存的なタウリン/ $\beta$ アラニントランスポ ーターの存在も明らかにした ${ }^{34,35)}$.

上述したのは脳内移行にかかわるトランスポーターで あったが, 汲み出しに働くため脳内移行障壁となるトラ ンスポーターもある. 小腸と同様に脂溶性にもかかわら ず脳内移行性の低い化合物は存在する. Fig. 6 にその 例を示すが，P-糖蛋白質の基質であるシクロスポリン や抗がん剂のビンクリスチンなどがその傾向を示す，脂 溶性とは対応しないこの低脳内移行は, 従来より血液脳 関門透過における分子量閾值によって説明されてきた.

これに対し1992年, 著者らは P-糖蛋白質による汲み出 し仮説を提唱した. すなわち, P-糖蛋白質が内皮細胞 血管側細胞膜に存在すること, $\mathrm{P}$-糖蛋白質阻害剤や ATP 枯渴によりビンクリスチンやシクロスポリンの脳 内移行性が in vitro, in vivo 両実験系で増大することを明 らかにした ${ }^{36-39)}$ 。また，1994年には P-糖蛋白質遺伝子 


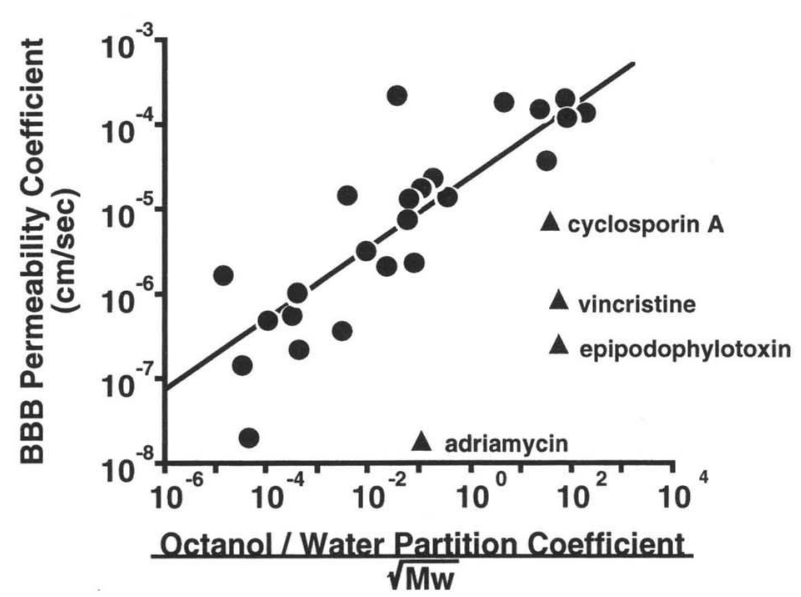

Fig. 6 化合物の脂溶性 - 分子量と血液脳関門透過性の相関

mdr1a 欠損マウスにおいて脳内移行増大が示され40), 能動的汲み出しにより血液脳関門機能の一部を $\mathrm{P}-$ 糖蛋 白質が担っていることが実証された.

血液脳関門トランスポーター研究はまだ始まったばか りであり, 今後新たなトランスポーターの発見が期待さ れる。

\section{4 排泄過程一肝・腎細胞膜透過一}

薬物の多くは尿中に排泄されるが，胆汁中排泄率の高 い薬物も存在し, 排泄経路決定因子は明らかではない. 薬物の脂溶性・分子量・タンパク結合と胆汁排泄を関係 ゔけた報告もあるが，必ずしも胆汁排泄機構を説明する ものではない，腎では尿細管上皮細胞膜透過が，肝では 肝実質細胞膜透過が含まれることから, 我々は膜輸送を 一つの因子と考え他の臓器との比較を含め両葴器細胞膜 輸送機構を検討した.

腎尿細管上皮細胞においては前述の小腸と同様なペプ チド輸送系が存在し, 系球体濾過されたペプチドの再吸 収に働いている41). 本トランスポーターは小腸と同様 にアミノー $\beta$-ラクタム抗生物質の再吸収に働くことも示 されていた42). 我々は小腸上皮細胞においてペプチド 輸送系を介するセフィキシムが腎でも同様に輸送される と考え, 腎尿細管上皮細胞刷子縁膜小胞を用いた検討を 行った ${ }^{43)}$. しかし, セフィキシムの輸送は担体介在型 ではあったがペプチド輸送系の関与はなく, むしろアニ オンとして尿中へと分泌方向に担体輸送されていること が示された. 同じ実験系でアミノー $\beta$-ラクタム抗生物質 の取り込みはジペプチドによって阻害されること, さら に $\left[{ }^{14} \mathrm{C}\right] \mathrm{Gly}-\mathrm{Sar}$ の取り込みがアミノ- $\beta$-ラクタム抗生 物質によっては阻害されるが，セフィキシムなどのアニ オン型誘導体によっては阻害されないという結果も得ら れた．以上の結果は，腎と小腸のペプチド輸送系は基質 認識性が異なることを示すものであった．体内での最終
処理段階となる腎の再吸収機構は, 体内侵入の最初の障 壁となる小腸上皮細胞と比して基質認識性が厳密であ り，これは栄養素のみを体内に保持する必要性がある生 理的必然性にかなう合理的機構と考えられた.

PepT1 は小腸 · 腎ともに分布するが，腎には PepT2 の特異的発現が最近明らかにされた ${ }^{44,45)}$. 両輸送系は基 質認識性が異なり, PepT2 は基質特異性がより高いと 考えられている. セフィキシムのようなアニオン型誘導 体は PepT2 による認識性が低いとすれば，この違いは 膜生理学的手法により得た我々の結果と対応するもので ある. 尿中分泌機構として両性イオン型 $\beta$-ラクタム抗 生物質については有機カチオン $/ \mathrm{H}^{+}$逆輸送系が, またほ とんどの誘導体に対して有機アニオン輸送系が関与して いる46-48).これら種々輸送系を介し, しかも誘導体ご とに寄与率が変動する複雑な分泌と再吸収機構により,

$\beta$-ラクタム抗生物質の腎動態が制御されているものと 考えられる.

一方, 肝においてはラット遊離肝細胞, 肝組織抽出法 および単離胆管腔側細胞膜小胞を用い，いずれの $\beta$-ラ クタム抗生物質にも有機アニオン輸送系を介した膜透過 のみが示された ${ }^{48-52)}$. 両性イオン型 $\beta$-ラクタム抗生物 質のアニオン輸送系への親和性は低く, これは両性イオ ン型誘導体の高い腎指向性と対応する. 本研究結果とし て, 血管側細胞膜透過性と $\beta$-ラクタム抗生物質の胆汁 中移行性とは必ずしも対応せず, 肝への取り込久過程は 胆汁中排泄の律速段階とはなりにくいことが示された. 一方, 胆管腔側細胞膜ア二オン輸送系に対する親和性と 胆汁排泄クリアランスとの間には良好な相関性が得ら れ, 本輸送過程が胆汁中排泄影響因子となることが示唆 された ${ }^{52)}$.

我々は胆管腔側細胞膜輸送系の重要性をin vivo で実 証するために，本細胞膜輸送機能欠損動物 (Eizai hyperbilirubinuria rat: EHBR) を用いた検討を行った. EHBR は抱合型ビリルビンの胆汁排泄を担う ATP 依存 的有機アニオン輸送機能を欠損したラットで黄疸症状を 呈する. また, 細胞膜小胞実験によって, ビリルビンと $\beta$-ラクタム抗生物質間に輸送系の共通性も示唆されて いる，そこで，胆汁中移行性の高いセフォペラゾンおよ び尿中排泄の大きなセファレキシンについて EHBR に おける肝動態を測定した53). その結果, セフォペラゾ ンの血中濃度推移は EHBR では正常動物に比べ高く維 持され, 肝固有クリアランスはほぼ $1 / 20$ に減少した. 一方, セファレキシンの肝固有クリアランスも約 $1 / 10$ に低下したが，血中濃度推移の変化は大きくなかった. また, 腎固有クリアランスはいずれも変動せず, 両抗生 物質間での体内動態変動性の違いは, 全クリアランスに 対する肝クリアランスの寄与率に依存するものと考えら れた。さらに EHBR から得た遊離肝細胞からのセフォ 
ペラゾンの排出は遅延したが，取り込みには両ラット間 で違いはなかった. 以上, $\beta$-ラクタム抗生物質の胆汁 中排泄には肝胆管腔側細胞膜の有機了ニオン輸送系が重 要であるという, 先に得られた結果が輸送機能欠損動物 を用いることにより実証された.

\section{5 おわりに}

以上, 種々薬物の吸収・分布 · 排泄過程に関わるトラ ンスポーターとその薬物動態への影響について述べた. $\beta$-ラクタム抗生物質は各臓器で機能する複数のトラン スポーターへの親和性が誘導体間で異なるため, 吸収性 や排泄経路が変動していることが示された．また，モノ カルボン酸系化合物についても機能するトランスポータ 一が蔵器ごとに異なる場合があり, トランスポーターを 利用した臓器特異的薬物デリバリーの可能性が示唆され た.さらに排出に働くトランスポーターも働いており, 薬物動態を予測・制御していく上で重要であることも示 された. 消化管吸収性が良好で肝初回通過効果が低く, しかも臓器移行性に選択性があるような薬物が理想的で ある. 脂溶性に従う単純拡散に頼る吸収性改善を行った 場合には, 初回通過効果が増大したり臓器移行性も非特 異的に増大する可能性が高い。このような観点から, 我 々はトランスポーター機能を利用した薬物動態制御が望 ましいと考えている．今後さらにトランスポーターの重 要性の定量的評価と薬物分子構造デザインに向けた研究 を進めたい。

謝 辞 : 本研究の成果を得るに当たり終始御指導をいただきま した金沢大学薬学部教授辻 彰先生と多大のご協力いただきま した教室員の皆様に 感謝いたします.

\section{文献}

1) Schaffer, J. and Lodish, H.: Expression cloning and characterization of a novel adipocyte long chain fatty acid transport protein. Cell, 79: 427-436 (1994).

2) Tsuji, A. and Tamai, I.: Carrier-mediated intestinal transport of drugs. Pharm. Res., 13: 963-977 (1996).

3) Addison, J. M., Burston, D., Dalrymple, J. A., Matthews, D. M., Payne, J. W., Sleisenger, M. H. and Wilkinson, S.: A common mechanism for transport of di- and tri-peptides by hamster jejunum in vitro. Clin. Sci. Mol. Med., 49: 313322 (1975).

4) Matthews, D. M.: "Protein Absorption", New York; Wiley-Liss, (1991).

5) Tsuji, A.: "Peptide-Based Drug Design: Controlling Transport and Metabolism", in M. D. Taylor and G. L. Amidon (eds), Washington D. C.; American Chemical Society, 1995, pp. 101-134.

6) Tsuji, A., Hirooka, H., Tamai, I. and Terasaki, T.: Evidence for a carrier-mediated transport system in the small intestine available for FK089, a new cephalosporin an- tibiotic without an amino group. J. Antibiotics, 39: 15921597 (1986).

7) Tsuji, A., Hirooka, H., Terasaki, T., Tamai, I. and Nakashima, E.: Saturable uptake of cefixime, a new oral cephalosporin without an $\alpha$-amino group, by the rat intestine. J. Pharm. Pharmacol., 39: 272-277 (1987).

8) Tsuji, A., Terasaki, T., Tamai, I. and Hirooka, H.: $\mathrm{H}^{+}$ gradient-dependent and carrier-mediated transport of cefixime, a new cephalosporin antibiotic, across brushborder membrane vesicles from rat small intestine. J. Pharmacol. Exp. Ther., 241: 594-601 (1987).

9) Tsuji, A., Tamai, I., Hirooka, H. and Terasaki, T.: $\beta$-Lactam antibiotics and transport via the dipeptide carrier system across the intestinal brush-border membrane. Biochem. Pharmacol., 36: 565-567 (1987).

10) Tamai, I., Tomizawa, N., Kadowaki, A., Terasaki, T., Nakashima, K., Higashida, H. and Tsuji, A.: Functional expression of intestinal dipeptide/ $\beta$-lactam antibiotic transporter in Xenopus laevis oocytes. Biochem. Pharmacol., 48: 881-888 (1994).

11) Tamai, I., Tomizawa, N., Takeuchi, T., Nakayama, K., Higashida, H. and Tsuji, A.: Functional expression of transporter for $\beta$-lactam antibiotics and dipeptides in Xenopus laevis oocytes injected with messenger RNA from human, rat and rabbit small intestine. J. Pharmacol. Exp. Ther. 273: 26-31(1995).

12) Fei, Y.-J., Kanai, Y., Nussberger, S., Ganapathy, V., Leibach, F. H., Romero, M. F., Singh, S. K., Boron, W. F. and Hediger, M. A.: Expression cloning of a mammalian proton-coupled oligopeptide transporter. Nature, 368: 563-566 (1994).

13) Miyamoto, K., Shiraga, T., Morita, K., Yamamoto, H., Haga, H., Taketani, Y., Tamai, I., Sai, Y., Tsuji, A. and Takeda. E.: Sequence, tissue distribution and developmental changes in rat intestinal oligopeptide transporter. Biochim. Biophys. Acta, 1305: 34-38 (1996).

14) Saito, H., Okuda, M., Terada, T., Sasaki, S. and Inui, K., Cloning and characterization of a rat $\mathrm{H}^{+}$/peptide cotransporter mediating absorption of $\beta$-lactam antibiotics in the intestine and kidney. J. Pharmacol. Exp. Ther., 275: 16311637 (1995).

15) Sai, Y., Tamai, I., Sumikawa, H., Hayashi, K., Amano, O., Numata, M., Iseki, S. and Tsuji, A.: Immunolocarization and pharmacological relevance of oligopeptide transporter PepT1 in intestinal absorption of $\beta$-lactam antibiotics. FEBS Lett, 392: 25-29 (1996).

16) Tsuji, A., Tamai, I., Nakanishi, M., Terasaki, T., Hamano, S., Intestinal brush-border transport of the oral cephalosporin antibiotic, cefdinir, mediated by dipeptide and monocarboxylic acid transport systems in rabbits. $J$. Pharm. Pharmacol., 45: 996-998 (1993).

17) Tamai, I. and Tsuji, A.: Carrier-mediated approaches for oral drug delivery. Adv. Drug Delivery Rev., 20: 5-32 (1996).

18) Tsuji, A., Simanjuntak, M. T., Tamai, I. and Terasaki, T.: $\mathrm{pH}$-Dependent intestinal transport of monocarboxylic acids: Carrier-mediated and $\mathrm{H}^{+}-$cotransport mechanism versus $\mathrm{pH}-$ partition hypothesis. J. Pharm. Sci., 79: 11231124 (1990).

19) Tsuji, A., Takanaga, H., Tamai, I. and Terasaki, T.: Transcellular transport of benzoic acid across Caco- 2 cells by a $\mathrm{pH}-$ dependent and carrier-mediated transport mechanism. 
Pharm. Res., 11: 30-37 (1994).

20) Takanaga, H., Maeda, H., Yabuuchi, H., Tamai, I., Higashida, H. and Tsuji, A.: Nicotinic acid transport mediated by $\mathrm{pH}$-dependent anion antiporter and proton cotransporter in rabbit intestinal brush-border membrane. J. Pharm. Pharmacol., (1996). (in press)

21) Tamai, I., Takanaga, H., Maeda, H., Yabuuchi, H., Sai, Y., Suzuki, Y. and Tsuji, A.: Intestinal brush-border membrane transport of monocarboxylic acids mediated by proton-coupled transport and anion antiport mechanisms. J. Pharm. Pharmacol., (1996). (accepted)

22) Tamai, I., Takanaga, H., Ogihara, T., Yoneda, M. and Tsuji, A.: Proton-cotransport of pravastatin across intestinal brush-border membrane. Pharm. Res., 12: 1727-1732 (1995).

23) Tamai, I., Takanaga, H., Maeda, H., Sai, Y., Ogihara, T., Higashida, H. and Tsuji, A.: Participation of a protoncotransporter, MCT1, in the intestinal transport of monocarboxylic acid. Biochem. Biophys. Res. Commun., 214: 482-489 (1995).

24) Takanaga, H., Tamai, I., Inaba, S., Sai, Y., Higashida, H., Yamamoto, $\mathrm{H}$. and Tsuji, A.: cDNA cloning and functional characterization of rat intestinal monocarboxylate transporter. Biochem. Biophys. Res. Commun., 217: 370-377 (1995).

25) Alper, S. L., Kopito, R. R., Libresco, S. M. and Lodish, H. F.: Cloning and characterization of a Band 3-related cDNA from kidney and from a lymphoid cell line. J. Biol. Chem., 263: 17092-17099 (1988).

26) 藪内 光, 高長ひとみ, 崔 吉道, 玉井郁已, 辻 彰, 薬物動態, 11: S194 (1996).

27) Terao, T., Hisanaga, E., Sai, Y., Tamai, I. and Tsuji, A.: Active secretion of drugs from small intestinal epithelium by $\mathrm{P}$-glycoprotein functioning as an absorption barrier. $J$. Pharm. Pharmacol., (1996). (in press)

28) Tamai, I. and Safa, A. R.: Competitive interaction of cyclosporins with the Vinca alkaloid-binding site of $\mathrm{P}-$ glycoprotein in multidrug-resistant cells. J. Biol. Chem., 265: 16509-16513 (1990).

29) Thiebaut, F., Tsuruo, T., Hamada, H., Gottesman, M. M., Pastan, I. and Willingham, M.: Cellular localization of the multidrug-resistance gene P-glycoprotein in normal human tissues. Proc. Natl. Acad. Sci. USA, 84: 7735-7738 (1987).

30) Tamai, I. and Tsuji, A.: Drug delivery through the bloodbrain barrier. Adv. Drug Delivery Rev., 19: 401-424 (1996).

31）稲葉真一, 高長ひとみ, 小野彰彦, 小村純子, 崔 吉道, 玉井郁巳, 辻彰, 薬物動態, 11: S170 (1996).

32) Yamazaki, M., Suzuki, H., Hanano, M., Tokui, T., Komai, T. and Sugiyama, Y.: $\mathrm{Na}^{+}$-independent multispecific anion transporter mediates active transport of pravastatin into rat liver. Am. J. Physiol., 264: G36-G44 (1993).

33) Tsuji, A., Saheki, A., Tamai, I. and Terasaki, T.: Transport mechansim of 3-hydroxy-3-methylglutaryl coenzyme A reductase inhibitors at the blood-brain barrier. $J$. Pharmacol. Exp. Ther., 267: 1085-1090 (1993).

34) Tamai, I., Senmaru, M., Terasaki, T. and Tsuji, A.: $\mathrm{Na}^{+}$ and $\mathrm{Cl}^{-}$dependent transport of taurine at the blood-brain barier. Biochem. Pharmacol., 50: 1783-1793 (1995).

35) Komura, J., Tamai, I., Senmaru, M., Terasaki, T., Sai, Y. and Tsuji, $\mathrm{A}$.: $\mathrm{Na}^{+}$and $\mathrm{Cl}^{-}$dependent transport of $\beta$-alanine across the blood-brain barrier. J. Neurochem., 67:
330-305 (1996).

36) Tsuji, A., Terasaki, T., Takabatake, Y., Tenda, Y., Tamai, I., Yamashima, T., Moritani, S., Tsuruo, T. and Yamashita, J.: P-Glycoprotein as the drug efflux pump in primary cultured bovine brain capillary endothelial cells. Life Sci., 51: 1427-1437 (1992).

37) Tsuji, A., Tamai, I., Sakata, A., Tenda, Y. and Terasaki, T.: Restricted transport of cyclosporin A across the bloodbrain barrier by a multidrug transporter, $\mathrm{P}$-glycoprotein. Biochem. Pharmacol., 46: 1096-1099 (1993).

38) Sakata, A., Tamai, I., Kawazu, K., Diguchi, Y., Ohnishi, T., Saheki, A. and Tsuji, A.: In vivo evidence for ATP-dependent and $\mathrm{P}$-glycoprotein-mediated transport of cyclosporin A at the blood-brain barrier. Biochem. Pharmacol., 48: 1989-1992 (1994).

39) Ohnishi,T., Tamai, I., Sakanaka, K., Sakata, A., Yamashima, T., Yamashita, J. and Tsuji, A.: In vivo and in vitro evidences for ATP-dependency of P-glycoprotein-mediated efflux of doxorubicin at the blood-brain barrier. Biochem. Pharmacol., 49: 1541-1544 (1995).

40) Schinkel, A. H., Smit, J. J. M., van Tellingen, O., Beijnen, J. H., Wagenaar, E., van Deemter, L., Mol, C. A. A. M., van der Valk, M. A., Rabanus-Maandag, E. C., te Riele, H. P. J., Berns, A. J. M. and Borst, P.: Disruption of the mouse mdr1a P-glycoprotein gene leads to a deficiency in the blood-brain barrier and to increased sensitivity to drugs. Cell, 77: 491-502 (1994).

41) Ganapathy, V. and Leibach, F. H.: Carrier-mediated reabsorption of small peptides in renal proximal tubule. Am. J. Physiol., 251: 945-953 (1986).

42) Inui, K., Okano, T., Takano, M., Saito, H. and Hori, R.: Carrier-mediated transport of cephalexin via the dipeptide transport system in rat renal brush-border membrane vesicles. Biochim. Biophys. Acta, 769: 449-454 (1984).

43) Tamai, I., Tsuji, A. and Kin, Y.: Carrier-mediated transport of cefixime, a new cephalosporin antibiotic, via an organic anion transport system in the rat renal brush-border membrane. J. Pharmacol. Exp. Ther., 246: 338-344 (1988).

44) Ganapathy, M., Brandsch, M., Prasad, P. D., Ganapathy, V. and Leibach, F. H.: Differential recognition of $\beta$-lactam antibiotics by intestinal and renal peptide transporters, PEPT1 and PEPT2. J. Biol. Chem., 270: 25672-25677 (1995).

45) Saito, H., Terada, T., Okuda, M., Sasaki, S. and Inui, K.: Molecular cloning and tissue distribution of rat peptide transporter PEPT2. Biochim. Biophys. Acta, 1280: 173 177 (1996).

46) Inui, K., Takano, M., Okano, T. and Hori, R.: $\mathrm{H}^{+}$ Gradient-dependent transport of amino-cephalosporins in rat renal brush-border membrane vesicles: Role of $\mathrm{H}^{+}$/organic cation antiport system. J. Pharmacol. Exp. Ther., 233: 181-185 (1985).

47) Nightingale, C. H., Greene, D. S. and Quintiliani, R.: Pharmacokinetics and clinical use of cephalosporin antibiotics. J. Pharm. Sci., 64: 1899-1927 (1975).

48) Tsuji, A., Terasaki, T., Tamai, I. and Takeda, K.: In vivo evidence for carrier-mediated uptake of $\beta$-lactam antibiotics through organic anion transport systems in rat kidney and liver. J. Pharmacol. Exp. Ther., 253: 315-320 (1990).

49) Tsuji, A., Terasaki, T., Takanosu, K., Tamai, I. and Nakashima, E.: Uptake of benzylpenicillin, cefpiramide and cefazolin by freshly prepared rat hepatocytes. Evi- 
dence for a carrier-mediated transport system. Biochem. Pharmacol., 35: 151-158 (1986).

50) Terasaki, T., Tamai, I., Takanosu, K., Nakashima, E. and Tsuji, A.: Kinetic evidence for a common transport route of benzylpenicillin and probenecid by freshly prepared hepatocytes in rats. Influence of sodium ion, organic anions, amino acids and peptides on benzylpenicillin uptake. J. Pharmacobio-Dyn., 9: 18-28 (1986).

51) Tamai, I. and Tsuji, A.: Transport mechanism of cephalex- in in isolated hepatocytes. J. Pharmacobio-Dyn., 10: 632638 (1987).

52) Tamai, I., Maekawa, T. and Tsuji, A.: Membrane potential-dependent and carrier-mediated transport of cefpiramide, a cephalosporin antibiotic, in canalicular rat liver plasma membrane vesicles. J. Pharmacol. Exp. Ther., 253: 537-544 (1990).

53）玉井郁巳, 崔 吉道, 杉山雄一, 过 彰, 日本化学療法 学会雑誌, 43: 952 (1995). 